\title{
Alguns apontamentos sobre a transformação da fome a partir da trajetória social do programa Fome Zero
}

\section{Notes on the transformation of the hunger through the analysis of the social trajectory of the Zero Hunger program}

Lis Furlani Blanco ${ }^{1}$

Atéo ano de 2010 não havia na Constituição Federal Brasileira o direito à alimentação básica. Esse processo de inclusão do direito à alimentação se deu em conjunto com diversas medidas do governo brasileiro desde 2003, sendo a principal delas o Programa Fome Zero. Quinze anos após sua criação, o programa ainda é tema de discussão, apesar de, atualmente, ter sido diluído em diversas políticas de segurança alimentar, e até mesmo distribuição e geração de renda.

Assim, é objetivo geral desta apresentação trazer alguns apontamentos sobre a transformação da fome, a partir da trajetória social do programa Fome Zero. Ao recuperar as discussões de Josué de Castro e José Graziano enquanto intelectuais paradigmáticos na construção da fome no Brasil, bem como a articulação desses atores em uma escala global e nacional, pretendo discutir as políticas públicas de combate à fome explorando as inter-relações construídas neste processo.

Como alguns autores clássicos da antropologia já apontavam para a possibilidade de entender a comida como um objeto diferente para aqueles que passam fome e para aqueles que tem suas necessidades satisfeitas, a exemplo de Audrey Richards, cabe perguntar como a fome é coordenada na construção prática de uma política pública que precisa definir, medir e avaliar para existir e, assim, como diversos saberes tecnopolíticos trabalham nesse processo de coagulação e transformação da fome.

Dessa forma, a comunicação pretende lançar luz à maneira em que o fenômeno da fome se transformou ao longo dos anos na "Insegurança Alimentar", e de que maneira essa transformação influi diretamente nos processos de feitura do Estado. Para tanto, desenvolvo uma etnografia da fome realizada nos documentos de criação do programa Fome Zero, mas também busco explorar as inter-relações construídas neste processo, as diferentes arenas em jogo e os diferentes sujeitos políticos que se projetavam e consolidavam em tais planos, compreendendo algumas categorias imbricadas nesta disputa, tais como a noção de direitos, assistência, vulnerabilidade e bem-estar social em ação/circulação/pauta.

Para tornar evidente essa transformação, apresento aqui uma análise dos aparatos institucionais criados a partir do Programa Fome Zero e as estruturas institucionais decorrentes desse processo. Trarei também alguns apontamentos sobre a tecnopolítica da fome e, por fim, buscarei elucidar as maneiras pelas quais as tecnologias de estado relacionadas à fome e, posteriormente, à Insegurança Alimentar passam a incidir sobre a vida de uma população, promulgando uma multiplicidade de associações que transformam a própria ideia de Estado e governamentalidade. 
Palavras-chave: fome; insegurança alimentar; Fome Zero; políticas públicas; Estado.

Keywords: hunger; food insecurity; Fome Zero; public policies; State.

1 Doutoranda em Antropologia Social no Instituto de Filosofia e Ciências Humanas da Universidade Estadual de Campinas. 